\title{
ANZTLA 30 ${ }^{\text {th }}$ Anniversary Speech@ Conference Dinner, Auckland 2015 by Kerrie Stevens
}

$\tau \mathrm{t}$ is my great pleasure to welcome you to the Conference Dinner of the 30th ANZTLA Annual Conference!

The Australian and New Zealand Theological Library Association, or as we know it ANZTLA, is celebrating its 30th anniversary this year and I consider it a privilege to be able to play a small part in that celebration.

I wonder if any of us can remember what we were doing 30 years ago...? I was lining up in Grade 3 to take my First Holy Communion, a new program called Neighbours started on TV, an athletic craze called Ironman was launched

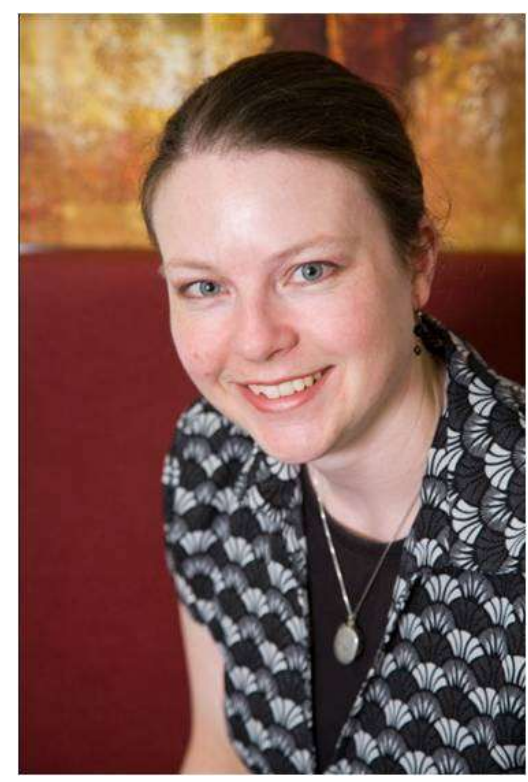
in Australia and a boat called the Rainbow Warrior was blown up, right here in Auckland.

At the time ANZTLA was formed, issues in the area of librarianship and particularly theological librarianship included library cooperation, collection strengths and weaknesses, professional development and recognition of librarians, collection development and user education - all just as important today.

The cooperation of libraries amongst ANZTLAs membership in today's theological education arena is immense and cannot be overstated or undervalued. Tonight, we have many members who have participated almost right from the beginnings of ANZTLA, but we also have a new generation of members who may have been members for only a couple of years, perhaps this is even your first conference - together we contribute to a most valuable enterprise for theological librarians in this region of the world. 


\section{"ANZTLA may be celebrating its $30^{\text {th }}$ anniversary today, but we are not resting on our laurels. There are many possibilities just around the corner. Many other \\ enhancements and projects are always only a short distance away."}

From its humble beginnings, unofficially in 1977, of ficially in 1985, ANZTLA has grown to be an unrivalled network of friends and colleagues with whom to share and resolve the various issues we all seem to face at one time or another. Whether we are a one-person library or a multi-campus, megastaff library - we all face the issues common to not just libraries, but special issues common amongst theological libraries. This collegiality is, I think, one of ANZTLAs greatest achievements. It doesn't matter what denomination your college is, or even what religion - library issues are library issues and they are common to us all.

It is comforting to see so many people returning year after year to the ANZTLA conferences. Today, as ANZTLA celebrates its 30th anniversary, it is able to proudly offer a number of invaluable theological resources to both librarians and researchers, students and faculty alike. The AULOTS union list of serials holdings in Australian and New Zealand theological libraries is a magnificent tool for tracking down an elusive article for a patron. The Australasian Religion Index, or ARI, supports members in their task as theological librarians. It is completely produced by ANZTLA members for ANZTLA members and the wider theological community and is an invaluable resource for researchers in the theological and religious periodical literature of our region. Its future is one being considered, but the contribution of all editors and indexers should not be forgotten. Rather it should be exalted and applauded for contributing to such a truly unique theological resource.

In addition, the ANZTLA Newsletter, and now the ANZTLA EJournal is a magnificent tool to spread the word and share the knowledge gathered, especially at the annual conferences. As an open access journal, it is freely available to any and all who may be interested. And just this year, we have entered into an agreement with EBSCO to have it included in a new research database which will hopefully extend its reach even further - a very exciting achievement indeed.

Also, ANZTLA utilizes its relationships with like-minded international organizations such as ABTPAL, ATLA, BETH 
"For 30 Years,

ANZTLA has

fostered the study

of theology and

religion by

enhancing the

development of

theological and

religious libraries

and librarianship." and ForATL to further the advancement of theological librarianship. Ties have never been closer, and by working together, we hope to increase the awareness of theological libraries around the world.

ANTZLA may be celebrating its 30th anniversary today, but we are not resting on our laurels. There are many possibilities just around the corner. Many other enhancements and projects are always only a short distance away.

It is the people gathering together, firstly to begin a coordinated effort to achieve national cooperation among theological and religious studies libraries; those who indexed and edited, and continue to do so, the thousands of contributions that make up ARI; those who gathered and edited AULOTS, first in print and then set it up for us all to manage cooperatively online; those who have been recognized by their peers for their significant contribution to the development of theological libraries in Australia or New Zealand in so many varied ways by being bestowed with a Trevor Zweck Award; those who have been honoured with Honorary Life Membership to ANZTLA for their outstanding and lasting contributions to theological libraries; those who have served in Board roles, ensuring our association heads in the right direction and is able to develop theological and religious libraries as best as possible; those who participate in regional chapters to continue the growth of ANZTLA locally, the support amongst colleagues and the professional development of those in the theological and religious library fields; and the numerous people over the years who have taken an aspect of ANZTLA, small as it may seem individually, and developed it into the best it could be - like the newsletter or ejournal, statistics, website management, ARI management, forum moderation, consortia organization, archives and JLSS coordinator - so many people have contributed to what ANZTLA is today and I take this opportunity to thank them all very sincerely.

For 30 years, ANZTLA has fostered the study of theology and religion by enhancing the development of theological and religious libraries and librarianship. We have often been at 'the cutting edge of librarianship', as Kim Robinson said many 
years ago, illustrated by the demonstration of electronic searching of databases only a few months after it was even possible in Australia. Just last year, I introduced QR codes into my library after learning about them at the 2014 Annual Conference - my faculty had never heard of them before and applauded me like I was some wiz bang tech-expert from a future age! We may take time to adopt new technologies but knowing about where the field is heading allows for planning and preparation to take place.

I am delighted that the 30th Anniversary is being celebrated here in Auckland with so many of you in attendance. I have every confidence that the future of ANZTLA will be every bit as successful and worthwhile as its very remarkable story has been so far.

Thank you 